
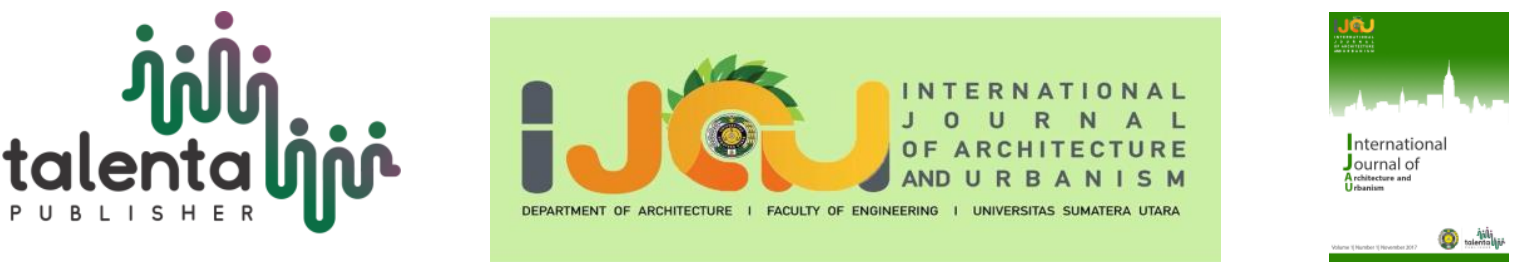

\title{
Revitalization Model of Medan City Based Home Shop as an Image-Forming Identity City
}

\author{
Deni Saadah Purba ${ }^{1^{*}}$, Dwi Lindarto Hadinugroho ${ }^{1}$ \\ ${ }^{1}$ Department of Architecture, Faculty of Engineering, Universitas Sumatera Utara, Medan, Indonesia
}

\begin{abstract}
The Shophouse is a multi-story building that has multiple functions. The 1st floor is used as a commercial area, and the 2 nd floor above is used as a residential place. Revitalization is an effort to revive an urban area through improving the quality of the environment, taking into accounts the socio- cultural aspects and characteristics of the region. The facade is the identity of the building itself by retaining elements and elements on the building façade. This research purposes of finding the dominant appearance of the elements of finding in the shophouse façade in the city of Medan, which is useful for the design revitalizing model of the face of the city as the image of the identity city. The method used in this study is qualitative descriptive, with a variable observation phase with the collection of primary and secondary data through direct observation in the field, then analyzed the shop facade elements that have been Grouped and found the most dominant element. The result of the analysis of the dominant facade element found in the shop façade of Medan is China, Malay, and India. The findings of the dominant facade element can be the identity identifier of the region and city of Medan today.
\end{abstract}

Keyword: elements facade \& facade, revitalization, shophouse

Received 12-07-2020 | Revised 15-07-2020 | Accepted 25-07-2020

\section{Introduction}

Medan City is the third-largest city in Indonesia and has a diversity of cultures and ethnicity. The diversity of culture and ethnicity has been mixed from local tribes such as Malay Deli, Karo, Batak Toba, Mining, Aceh, and Javanese, as well as foreign tribes such as India, Europe, and China. The development of city development as a place of settlement is not detached from the history of City face formation.

Typical Shophouse is categorized as Urban Vernacular-Architecture which is a vernacular architecture located in the urban area. The vernacular buildings are ordinary, innocent, lowcaste, low-cost, or built by traditional groups using timeless and unchanging local cultures. In its utilization, the construction of shophouse become uncontrollable due to the lack of respect for

\footnotetext{
*Corresponding author at: Department of Architecture, Faculty of Engineering, Universitas Sumatera Utara, Jalan Perpustakaan Gedung J07, Medan 20155, Indonesia
} 
occupancy and non-residential conditions to the diversity of ethnicity in the city mixed in the region, so that the shop building is branded as a building Damage to the city's face and cause a loss of identity.

Based on a study on the face of the city of Medan with its ethnic diversity affecting the shophouse, the purpose of this research is to identify, classify, and reveal the elements of identity-forming based on ethnicity Contained in the façade of Medan Shophouse as Urban Vernacular-Architecture using finding the dominant appearance of the element is in the shophouse façade in the city of Medan which is useful for the design revitalizing model of the city face as the image of the city identity.

\section{Literature Review}

Suburban Retrofitting Approach, Retrofitting is defined as an urban retrofitting that is an appropriate approach and idea of rehabilitation or reuse that includes the system, has long-term prospects, and transformative changes. Retrofitting aims to re-utilize an object appropriately as one way of developing an object [1]. Shop House is a typical urban building with dual function as a place of business (trade) as well as residential (residential). Row Ruko itself is a building that initiated business activities, especially trading activities in a region that then, as the development of the city, became a center of trade and services with various business activities [2]. Revitalizing, the arrangement and revitalization of the region according to the Department of Kimpraswil (2002) is a series of efforts to revive areas that tend to die, enhancing the strategic and significant vitality values of the region that still have potential and Control areas that tend to be chaotic [3]. Façade, The advance composition, considers the functional requirements, relating to the unity of excellent solution proportions, harmony, and harmony, the preparation of structured horizontal and vertical elements, materials, colors, and other decorative elements [4].

\section{Methodology}

This type of research is qualitative descriptive research. Descriptive research is a study describing an object, in this case, a shophouse in the city of Medan. The samples in this study were selected through the purposive sampling method. The object in the study is the shop in Jl. Brigadier General Katamso (Sei Mati), Jl. Sutrisno (Matsum), Jl. Teuku Cik Ditiro, Teuku Umar, Kediri (Madras Hulu), Jl. Perdana, Kumano, Gwangju (Kesawan), and Jl. Jamin Ginting (Pancur Batu). The criteria mentioned in this research include the façade element of the shop building that looks the most dominant in the selected area. Qualitative research is conducted by conducting observation directly to the research site. The research variables to be examined in this study are the façade of the shophouse building on the area studied in the form of building facade elements such as doors, windows, walls, ornaments, and roofs. The research results in 
the form of findings of the dominant façade element found in the shophouse façade and become the identity identifier of the city.

\section{$4 \quad$ Result and Discussion}

Facade Shop Element Analysis

Door, Elements of the door on the building are important roles, especially in the fire shophouse whose principal function is a business precisely located on the 1st floor and also as a residential house for the owner who is on the 2nd-floor shop. Moreover, every shophouse certainly has a different door façade. In the shop there are seven categories of doors, as follows: (Type A) rectangular door with half mesh-nets, folding door type, brown color, and material with iron, (Type B) Folding door/folding gate type, brown colored, steel material, (Type C) Folding door, with iron material, and blue color, (Type D) Folding door, with iron material, curved pattern on the entire door and colored in blue, (Type E) Folding door, with iron material, has a geometric pattern of box and round on all doors and brown color, (Type F) Folding door, with iron material, has an extensive checkered geometric pattern on the door, and yellow color, (Type G) Folding door, with iron material, has a pattern, colored green, this type of door there are many cracks (lattice latticework).

As for the most dominant door seen in this area is the door type folding door/folding gate type. This type of door has existed since the 2000s, and until now, many people use it because of its lightweight material and the way to open it just by pushing it towards the right and left of the door (Figure 1).

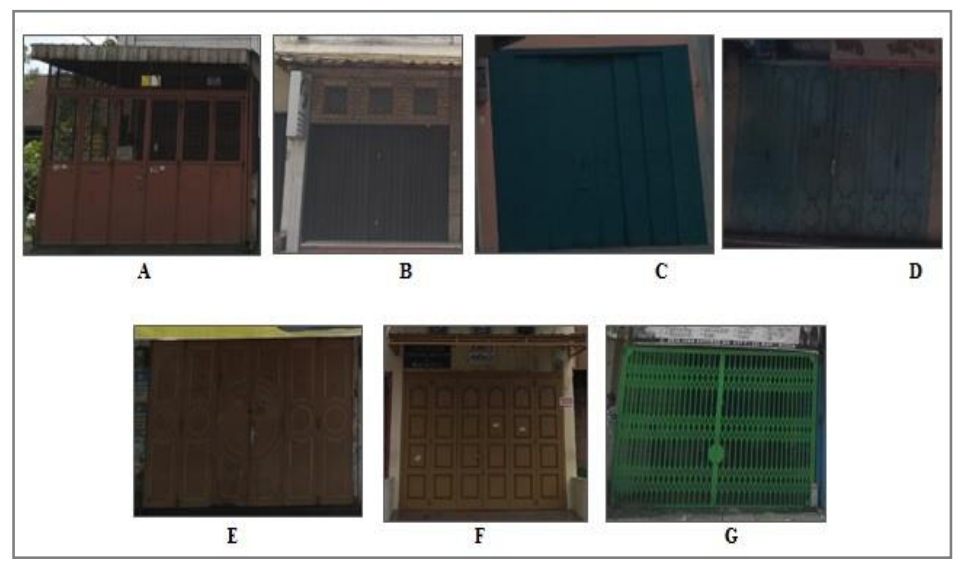

Figure 1 Door Type

Windows are an element of the façade which is quite an urgent action to play mainly on the façade of the building in any form and type. Windows can also provide aesthetic value if coupled with ornaments on the façade of the window and can give an identity to the building itself. In the shop there are six categories of Windows, as follows: (Type A) The window with the latticed grille on the front of the façade, some ornaments reflect the Chinese flower motif of Chinese, iron-material, yellow color, (Type B) The window with the latticed grille on the front 
of the façade, some ornaments reflect the Chinese motif of Chinese flower, iron material, white, (Type C) Arc-shaped window on the top, consisting of 4 rows of windows, dark glass-material windows, (Type D) The square-shaped window extends almost to the entire wall, with a dark glass material, a white window, with a nonpermanent canopy cover topped, (Type E) The window with the latticed grille is the front of the façade, the iron-material, dark brown, (Type F) Window is lined up three pieces of window, dark Nako glass, there are curved ornaments with decorative Malay motif on the top of the window, dark brown wood frame.

Based on the types of Windows above, it is known that the window with the dominant form of a square window with a touch of lattice - patterned pattern or Chinese decorative motif that is type A and B, and other type D and F Windows Form that almost Same but distinguishing is the formation of arch ornaments that exist in type F. Formation type A and B is essentially a type of old window, which is the type of window used by Chinese society to date. While type C, D, F type Modern window (Figure 2).

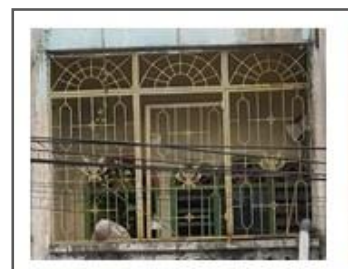

A

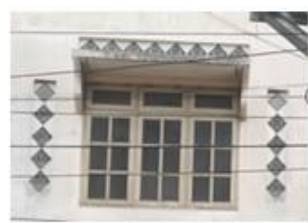

D

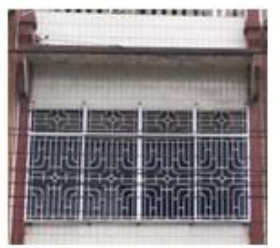

B

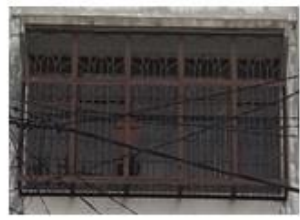

E

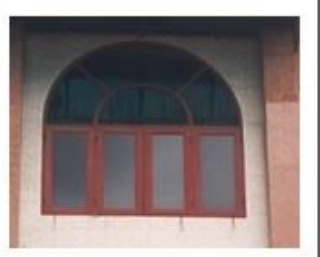

C

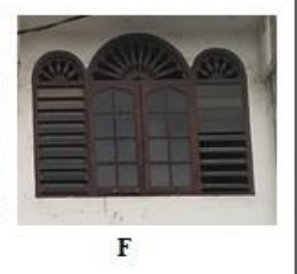

$\mathbf{F}$

Figure 2 Window Type

The wall is a building facade element that plays an essential information role in the formation of a building façade that can reinforce the characteristics and character of a building. The surface of a wall can be highlighted through attractive wall processing from material selection, paint, texture, color, and also manufacturing techniques. In the shop there are six categories of walls, as follows: (Type A) Fine stucco wall, not much ornament, color looks faded, there is such a fence do balcony area, (Type B) Stucco wall with white ceramic wall cover, no ornament, the wall looks plain and simple, (Type C) Ceramic covered stucco wall, red-colored, no ornaments, (Type D) Stucco wall with ceramic wall cover in green white, with window in the middle, (Type E) Fine brown cement plaster wall, no ornaments, (Type F) Fine stucco wall, peach-colored with a balcony arrangement-a balcony on the wall, there is a pyramid ornament on each of the balcony façade.

Based on the types of walls above can be known that the type of wall in the dominant shophouse using stucco wall material with ceramic wall coverings. With wall facades that tend to be 
monotonous without any ornaments on the wall. Color - The color used only using the colors of brown, peach and, light brown (Figure 3).

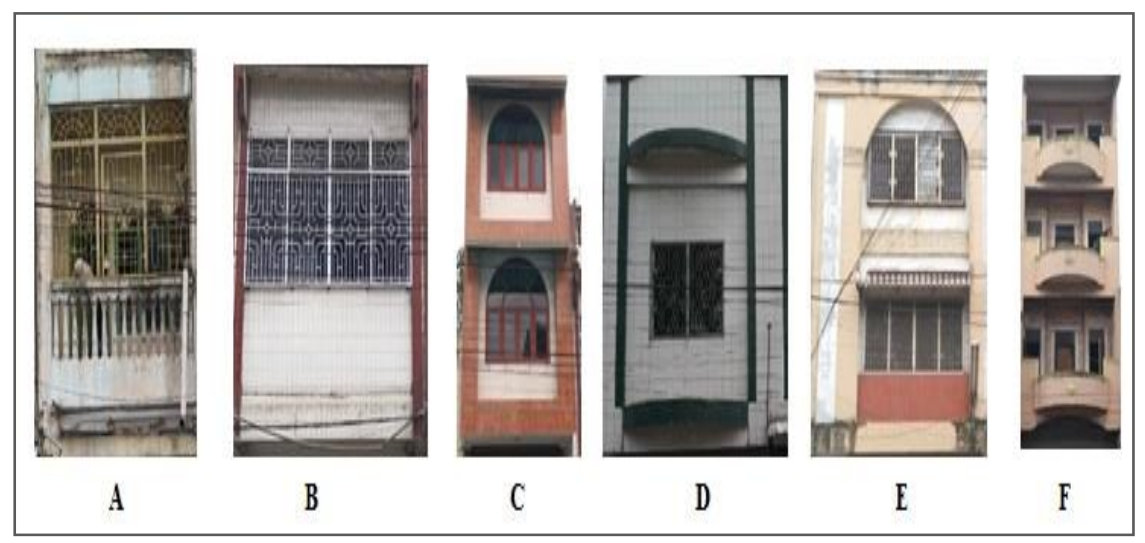

Figure 3 Wall Type

Ornaments are the most critical element in the façade of a building. They are also included in the shop building. Ornaments on each building can necessarily affect the aesthetic value or the beauty of the building facade. At the Shophouse 7 category ornaments, as follows: (Type A) ornament motif creation/delusion of Indian gods located at the shop door, sticker ornaments are pasted, (Type B) Indian flower Plant ornament, table on the shop wall, cement material formed like a flower, (Type C) Indian flower plant ornaments, found at the top of the door, to the glass, (Type D) Ornament creations/delusion of Indian gods, located on the wall of the floor one shop, precisely located on the right side and also left the shop, (Type E) The geometric ornament of the box is lined up at the top of the door, (Type G) Indian flower Plant ornament, cement material formed to resemble a flower, white and fringed in front façade on balcony shop. Based on the types of ornaments above, it can be noted that there are still several shophouses presenting the identity of his façade through these ornaments are Indian ornaments (Figure 4).

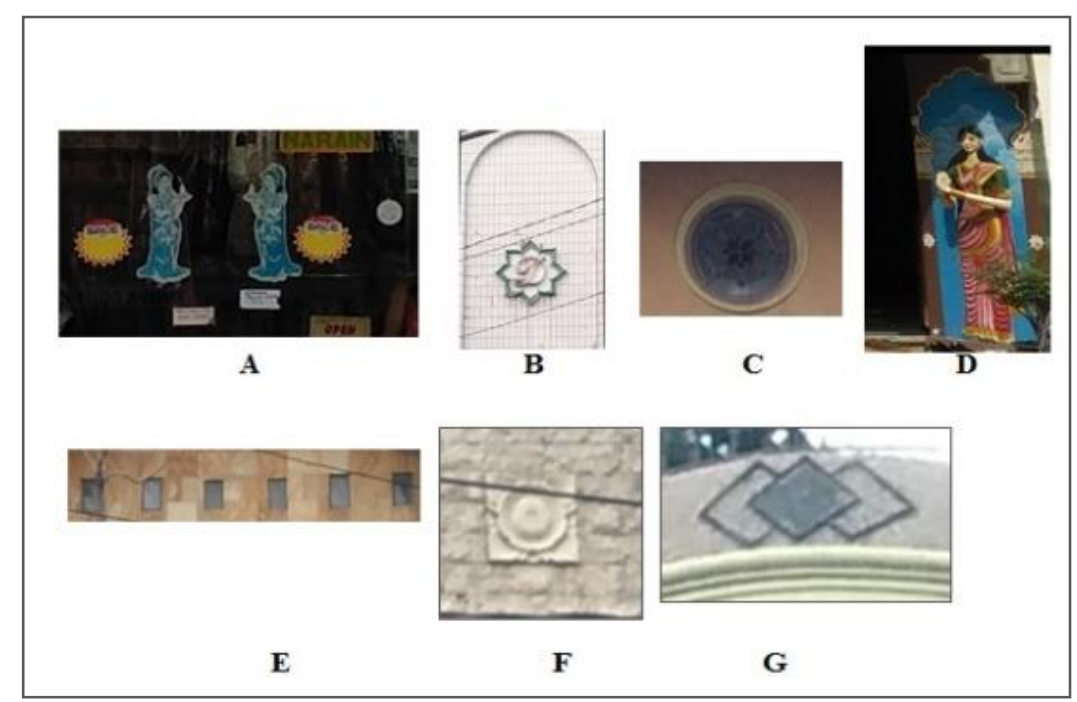

Figure 4 Types of Ornaments 
The Roof of a building plays a very important role. As the roof is the head that sits at the top of a building as the inner cover of the building. Without the roof, the building will look strange and not proportionate. In the shop there are nine roofing categories, as follows: (Type A) Flat roof dark Concrete, with nonpermanent canopy on the front of the roof facade, (Type B) Flat roof dark Concrete, with a short iron fence on it also there is a small canopy as a barbed of the shop, (Type C) The roof adopts the dome-like Dome of the Indian place of worship, (Type D) Flat roof dark Concrete, with arch that stands out fore shop building, (Type E) Flat roof dark Concrete, there are additional zinc saddle roof precisely located on the rooftop, (Type F) Flat roof dark Concrete, with a Malay fence right at the top of the shop, (Type G) Flat tap, there is a long iron fence at the top of the building up the shop. On the rooftop, (Type H) Flat roof dark Concrete with arch protrusions on the façade area of the building, there is additional is the roof of the zinc saddle, (Type I) Saddle roof, zinc-materially, with Indian flower ornaments, redwood lisp lank. Based on the type of roof above can be known that the door D and G type are most dominant used in the façade-shop façade at this time (Figure 5).

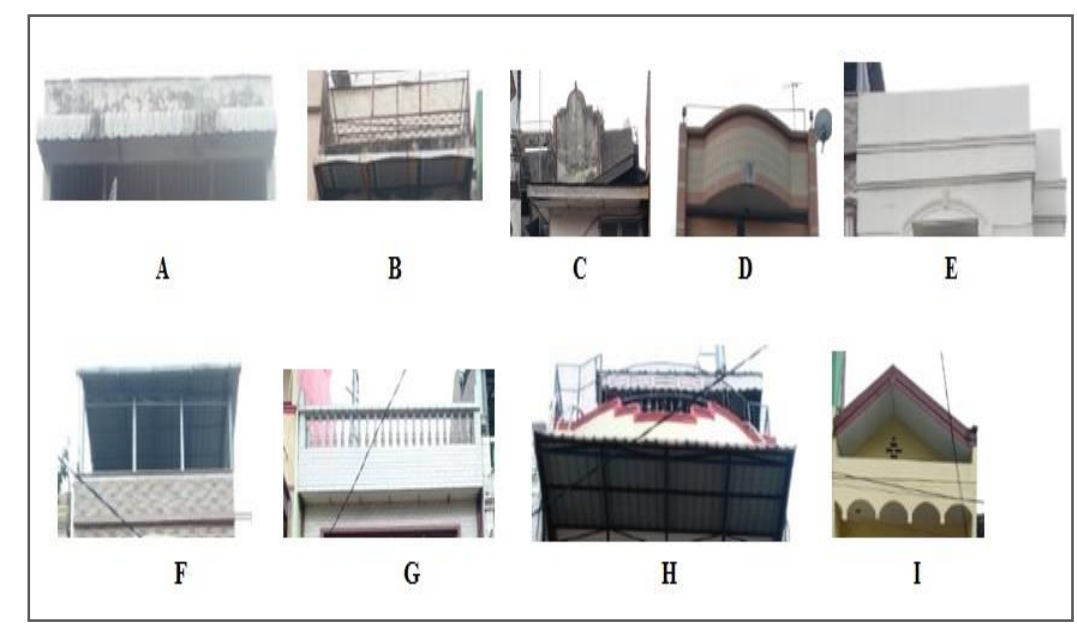

Figure 5 Type of Roof

Based on the types of elements above can be concluded, it has changed both in terms of material and its shape. In each of the research, areas have been found elements of the façade that still characterizes the identity of a shop building itself.

Based on the image above is a map of the shop dots in Medan that feature elements of ethnic identity that is Malay, Chinese, and Indian. In each of the research areas in the city of Medan can be noted that in every area of course has been the ethnic intermingling among the ethnic one with the other. So it is undeniable that it affects the shop building as its residence which gives each character its ethnic identity (Figure 6). 


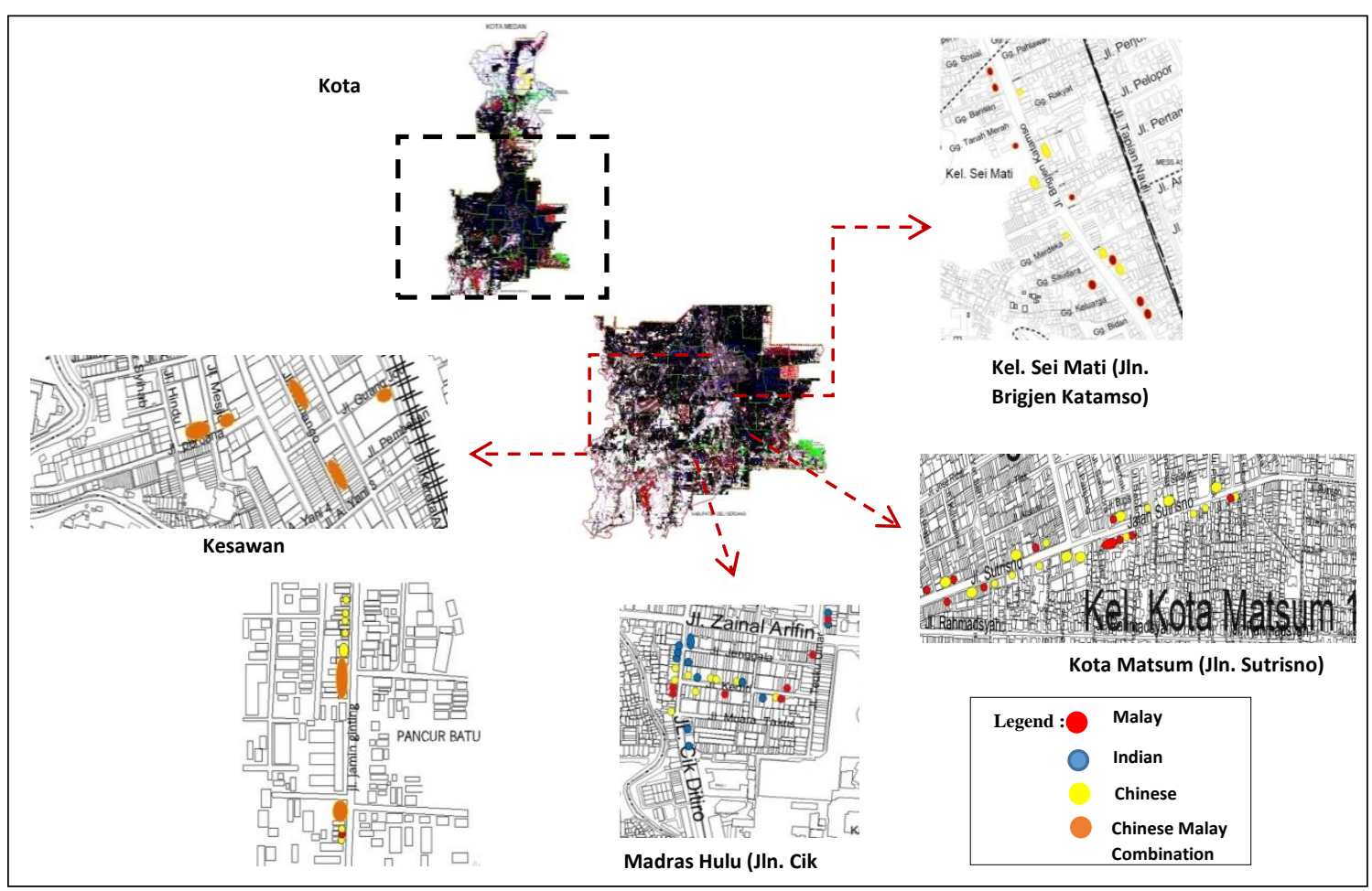

Figure 6 Map of Shophouse Spots in Medan

Findings of a Shop Facade Element Analysis

Based on the analysis of model revitalization of the Shophouse elements above, it has been found the dominant elements contained in the shop façade are windows, doors, walls, ornaments, and roofs as well as poles. Therefore, in this sub-chapter, the researcher summarizes the findings obtained from the model analysis revitalizing elements of the shophouse elements consisting of 3 shophouses Chinese, Malay, and Indian.

The form of a shop that exists today has a similarity that is on elements of the pillars such as doors, doors used today are dominant using the rolling door and additional iron bars in the outer part. Then for the window, the window that can be found and the most dominant is the dark glass dead window with the lattice (China), the window with arch ornament on it (India), and a window full of the latticed lattice with an additional Malay ornament. Plain, ornamental, and ceramic stucco wall. Chinese floral ornaments on the lattice trails, Fengshui and decorative Chinese ornaments, typical Indian floral motif ornaments, as well as the motifs of Indian gods and dominant roofs using flat roofs cast concrete. Model Revitalizing shop on the picture above is a shop that we can find in the city of Medan, and obviously, one can also know the shophouse that still gives a characteristic of its ethnic identity through the dominant elements found in the shop façade (Figure 7). 


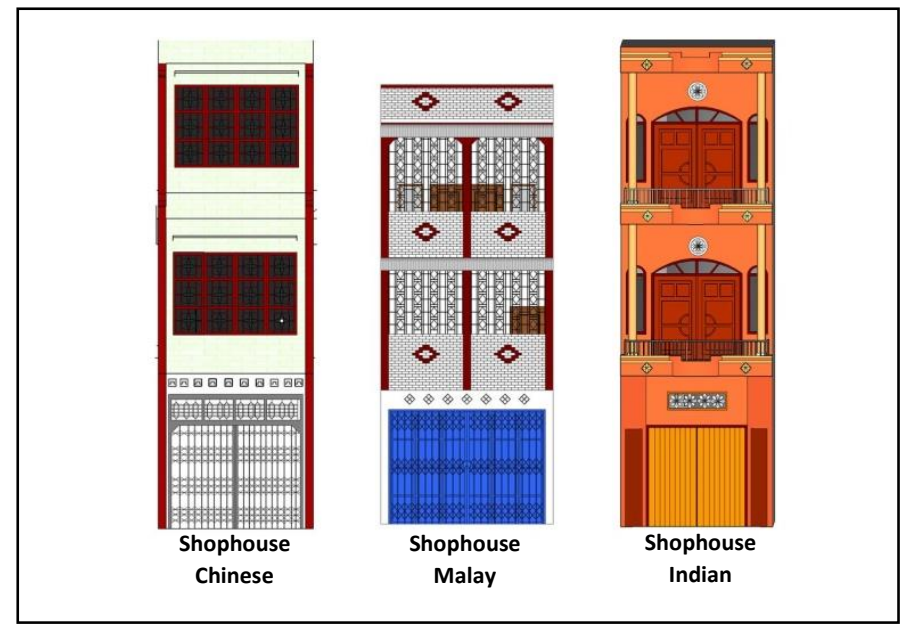

Figure 7 A Representative of the Dominant Elements on the Shop House Facade

\section{Conclusion}

It has been found a model of the store's home revitalization of the dominant elements found on Chinese, Indian, and Malay shophouses facades. Based on the three shophouses, this shop is the dominant element that is, of course, a hallmark or ethnic identity which can obviously is useful as a revitalizing city facing model. Here are the dominant elements found in the shop façade: (Chinese Shophouse) The dominant elements in the Chinese shophouse are the concrete flat roof, dark stained glass windows with a decorative lattice Chinese flowers, iron doors with extra jerjak, white plain stucco wall, and Feng shui ornaments and Decorative Chinese motifs that are usual on the wall especially the upper part of the 1st floor as identification or the owner's identity,(Shophouse India) The dominant elements found in the Indian shophouse façade are using a flat concrete roof, dark glass windows with curved ornaments topped, orange stucco wall, a typical Indian decorative floral ornament that is commonly found on the wall 1st floor in the upper area of the door, also there are decorative ornaments of gods motifs that are also usually found on the doors and areas of the wall of the 1st floor, and (Shop Malay) The dominant elements found in the Malay shophouse façade are using a flat concrete roof, a window full of Malay decorative latticework, stucco walls with white ceramics, geometric ornaments like a typical Malay shape kite that Can be found on the wall.

\section{Acknowledgment}

The research is a study of a shophouse to find the appearance of dominant elements in the shophouse facade in Medan city, which is useful for the design of the city face revitalization model as the city of identity.

\section{REFERENCES}

[1] Dunham- jones, e., \& Williamson, j, Retrofitting Suburbia: urban design solutions for redesigning suburbs. Hoboken, NJ: John Wiley \& sons, 2009. 
[2] Erdiono, D., Karonkong, H.H. and Siregar, F.O., "Studi Peng'amatan Terjadinya Pola Pergeseran Fungsi Ruang Pada Bangunan Rumah-Toko Di Manado," Media Matrasain, 9(3), pp.47-66, 2012.

[3] Kimpraswil. "Pedoman Umum Program Penataan dan Revitalisasi Kawasan, Departemen Permukiman dan Prasarana Wilayah Direktorat Jenderal Tata Perkotaan dan Tata Perdesaan", Jakarta, 2002.

[4] Krier, R, Komposisi Arsitektur, Jakarta, Penerbit Erlangga, 2001. 